\title{
TINGGALAN TRADISI MEGALITIK DI KAMPUNG KOKAS, KOMBIF, SUN WABAN KABUPATEN MAYBRAT \\ (Megalithic Tradition in Village of Kokas, Kombi Sun-Waban, Maybrat \\ Regency)
}

\author{
Klementin Fairyo \\ Balai Arkeologi Papua Jalan Isele, Kampung Waena, Distrik Heram, Kota Jayapura 99358 \\ Telepon (0967) 572467, Faksimile (0967) 572467 e-mail: fairyoklementin@yahoo.co.id
}

\begin{tabular}{l} 
INFO ARTIKEL \\
\hline Histori artikel \\
Diterima: 26 Februari 2016 \\
Direvisi: 18 Maret 2016 \\
Disetujui: 17 Mei 2016 \\
\hline
\end{tabular}

\section{Keywords:}

Maybrat,

megalithic remain,

megalithic tradition

Kata kunci:

Maybrat,

peninggalan megalitik,

tradisi megalitik

\begin{abstract}
The remains of the megalithic tradition in Papua since prehistoric times. Megalithic relics are not only found in coastal areas, but also found in the interior. This paper aims to describe and analyze the relic, the function and role of the remains of the megalithic tradition for the community supporters. The method used is a literature study, observation, and interviews. The results of field observations are megalithic structures and totor. Processing data includes identification and archaeological data description and ethnoarchaeology.
\end{abstract}

\begin{abstract}
ABSTRAK
Tinggalan tradisi megalitik di Papua sejak masa prasejarah. Peninggalan megalitik tidak hanya ditemukan di daerah pesisir saja, tetapi juga ditemukan di pedalaman. Tulisan ini bertujuan mendeskripsikan dan mengkaji bentuk peninggalan, fungsi dan peran tinggalan tradisi megalitik tersebut bagi masyarakat pendukungnya. Metode penelitian yang digunakan adalah studi kepustakaan, observasi lapangan, dan wawancara. Hasil observasi lapangan adalah struktur bangunan megalitik dan totor. Pengolahan data meliputi pengindentifikasian dan pendeskripsian data arkeologi dan etnoarkeologi.
\end{abstract}

\section{PENDAHULUAN}

Tradisi megalitik merupakan suatu bentuk tradisi yang munculpada masa neolitik yaitu sejak 4500 tahun yang laludan bahkan terus berkembang hingga sekarang ini. Kehadiran tradisi megalitik ditandai denganpendirian bangunan-bangunan dari batu yang pada umumnya untuk tujuan pemujaan dan tanda peringatan. Selain itu, ada juga dalam bentuk cerita-cerita atau dongeng-dongeng suci. Tradisi megalitik mengalami kemajuan pesat didukung dengan sumber daya alam di sekitarnya dan perkembangan budaya lokal yang mempunyai ciri-ciri tersendiri. Kehadiran tradisi megalitik dalam perkembangan budaya manusia merupakan salah satu bukti terbentuknya suatu peradaban.
Meskipunbiasadikaitkandengan masa prasejarah, tradisi megalitik tidak mengacu pada suatu era peradaban tertentu, namun lebih merupakan bentuk ekspresi yang berkembang karena adanya kepercayaan akan kekuatan magis. Soejono (1993:205), menjelaskan bahwa kebudayaan megalitik merupakan istilah untuk menyebutkan kebudayaan yang menghasilkan bangunan-bangunan dari batu besar. Mega berarti besar dan lithos berarti batu, kebudayaan megalitik selalu berdasarkan pada kepercayaan akan adanya pengaruh kuat dari salah satu objek yang telah mati, terhadap kesehjahteraan masyarakat dan kesuburan tanaman. Objek-objek yang berukuran kecil, dan bahan-bahan seperti kayupun harus dimasukkan ke dalam klasifikasi 
megalitik bila benda-benda itu jelas dipergunakan untuk tujuan sakral tertentu, yakni pemujaan kepada arwah nenek moyang. la juga menguraikan bahwa sisa-sisa peninggalan budaya dari masa prasejarah dikelompokkan dalam beberapa masa yaitu masa hidup berburu dan mengumpulkan makanan, masa bercocok tanam, dan masa perundagian (Soejono, 1993:205).

Wilayah Papua telah mendapat pengaruh megalitik dari Asia Tenggara melalui dua jurusan yaitu pengaruh pertama datang dari barat melalui Indonesia sebelah selatan lewat Kepulauan Maluku menuju bagian barat Papua dan pengaruh kedua menyebar ke Mikronesia sebelum membelok ke arah barat menuju Sepik di Papua New Guinea melalui Filipina, Sulawesi Utara, dan Halmahera (Soejono, 1994:30).

Budaya megalitik di Papua dapat ditemukan di wilayah Nafri berupa menhir dan meja batu (Mene dan Djami, 2014:8), di Sentani berupa menhir, batu berjajar, pahatan batu, batu tamugelang dan lukisan pada bongkah-bongkah batu (Djami, 2009:56) di Depapre berupa arca megalitik dan batu tamugelang (Mene, 2013:20), di Pulau Batanta berupa Benteng Yenbekaki (Suroto et. al., 2009:20), dan Misool berupa benteng keramat Claudi (Tim Peneliti, 2010:27), di Pulau Adi berupa meja batu (Soejono, 1994:28).

Melihat persebaran peninggalan megalitik di atas seolah-olah tradisi megalitik tidak sampai ke wilayah pedalaman Papua, namun tidak demikian adanya, karena berdasarkan pada beberapa hasil penelitian arkeologi yang dilakukan di wilayah pedalaman Papua seperti di wilayah Bomakia ditemukan arca megalitik
(Kawer et. al., 2014:10), batu penanda kubur ditemukan di Mamberamo Tengah (Suroto, 2014:14) dan bahkan ciri-ciri budayanya masih dapat ditemukan dalam beberapa aspek kehidupan masyarakat pedalaman Papua hingga saat ini.

Jejak tinggalan megalitik dan ciri budayanya di wilayah Pedalaman Papua Barat, dapat dijumpai di Kampung Kombif dan Sun-Waban, Distrik Mare dan Kampung Kokas, Distrik Aifat Barat, Kabupaten Maybrat. Tinggalan megalitik tersebut berupa susunan batu berbentuk persegi panjang dan situs bentukan alam, situs bentukan alam ini dikaitkan dengan mitos munculnya kain timur. Selain itu, ada juga tempat-tempat keramat yang disebut totor. Totor adalah tempat menghias atau dekorasi arwah orang mati. Hingga kini, keberadaan totor masih mempengaruhi alam pikir ataupun kepercayaan masyarakat Maybrat, bahwa totor merupakan tempat bersemayamnya arwah keluarga orang yang sudah meninggal dan mereka menganggap bahwa arwah tersebut masih ada dan mampu memberikan perlindungan kepada keluarga yang ditinggalkan.

Peninggalan megalitik di wilayah Distrik Mare berupa susunan batu berbentuk persegi panjang yang ditemukan di Situs Kocuata di Kokas serta situs bentukan alam dan cerita rakyatyang melatarbelakanginya, maka tulisan ini hendak mengkaji bentuk tinggalan tradisi megalitik, fungsi dan peran tinggalan tradisi megalitik dalam kehidupan sosial budaya masyarakat pendukungnya khususnya di wilayah Kokas, Distrik Aifat Barat dan wilayah Distrik Mare, Kabupaten Maybrat.

\section{Cerita Rakyat}

Masyarakat Aifat Barat 
khususnya di Kampung Kokas, Aifat Barat mempunyai cerita lisan terkait keberadaan tinggalan megalitik di wilayahnya. Adapun cerita lisan sebagai berikut (wawancara dengan Kornelius Kocu).

"Nenek moyang klan Kocu adalah Tefof Kocu yang dahulunya tinggal di daerah Jitmau dan berteman dengan Jitmau, hasil dari pertemanan mereka tersebut, Jitmau memberikan istri keduanya kepada Tefof Kocu untuk dikawini dan hasil perkawinan mereka lahirlah Kosata dan seorang anak perempuan lainnya. Keberadaan Kosata ini merupakan awal mula kehidupan di Kampung Kocuata di mana Kosata hidup berdua dengan saudara perempuannya.

Di dekat Kampung Kocuata ini terdapat kampung lainnya yang dihuni oleh Kocuiyas dan anak perempuannya, dan antara Kocuiyas dan Kosata mereka telah hidup berdampingan cukup lama dan bahkan terjadi pemberian kain timur oleh Kosata kepada Kocuiyas dengan perantara babi dan tiupan alat musik triton, adapun status kain timur yang diberikan oleh Kosata tersebut telah menjadi hutang bagi Kocuiyas yang harus dibayar atau dilunasi nantinya.

Seiring perjalanan waktu, Kocuiyas bertemu dengan seorang laki-laki lain yang datang ke tempatnya bernama Ahah yaitu seorang Karon suku Hae yang memperkenalkan kapak besi kepada Kocuiyas dan menggantikan kapak batunya, akibat pertemanan antara Kocuiyas dan Ahah maka ia memberikan anak perempuannya untuk diperistri oleh Ahah, dan Ahah berjanji akan memberikan kain kepada Kocuiyas untuk diberikan kepada Kosata dan janjinya dipenuhi setelah tiga hari Ahah datang dengan berpakaian lengkap didampingi istrinya dan membawa kain timur (toba mboh) ke tempat Kocuiyas yang kemudian dibawa ke tempat Kosata dan di halaman rumah kosata yaitu di area yang terdapat struktur batu (tinggalan megalitik) di sinilah proses pelunasan hutang dimulai yaitu Kucuiyas mengikatkan kain timur bawaannya pada ekor babi Kosata kemudian menyerahkannya kepada Kosata, kemudian babi tersebut dibunuh dan dibagi dua sebagian untuk Kucuiyas dan sebagian lagi untuk Kosata, dengan demikian berakhirlah hutang piutang antara Kosata dan Kocuiyas".

Selain ceritera tersebut di atas, juga ada ceritera lainnya yang berkaitan dengan pemanfaatan tinggalan megalitik, yaitu bahwa Kosata dengan meniup alat musik tritonnya mampu mengumpulkan kain timur dari berbagai tempat yang dilakukan di area struktur batu di halaman rumahnya. Oleh karena begitu hebatnya Kosata, maka ia memiliki banyak kain timur yang diwariskan kepada anak Wehenif Kocu, dan diteruskan kepada Wensewu Kocu dan dari Wensewu Kocu yang mengawini enam orang perempuan.

Kain timur warisan tersebut kemudian dibagi-bagikan kepada keturunannya dari lima istrinya saja, dan tidak diberikan pada turunan dari istri yang ke-enam, sehingga istrinya tersebut membawa anaknya dan pergi keluar dari kampung. Sedangkan empat anak lainnya yang diberi kain timur adalah Kocu U, Kocu Pau, Kocu Haifat dan Kocu Emon,dan merekapun pergi mencari tempat tinggalnya masing-masing,sedangkanyang tetap tinggal di kampung tua (ata) adalah Kande Kocu.

Diantara kain timur yang dibagikan di Situs Kocuata, salah satu kain yaitu toba mboh masih diwariskan. 
Kain toba mboh disimpan oleh Yanpit Kocu.Oleh karena kesakralannya, kain toba mboh ini tidak diperbolehkan diperlihatkan kepada Tim Peneliti. Toba mboh merupakan kain pusaka. Toba mboh dapat dikeluarkan dari tempat penyimpanan dan diperlihatkan kepada keluarga jika anak pertama dalam keluarga Kocu meninggal (wawancara Kornelius Kocu).

\section{Metode Penelitian}

\section{Penelitian ini menggunakan metode pendekatan kualitatif dengan sifat penelitian deskriptif, dan bentuk penalarannya induktif. Tipe pendekatan tersebut dilakukan yaitu dengan mendeskripsikan data dari kasus-kasus yang berhasil diperoleh dilapangan,kemudian dianalisis atau dibahas secara mendalam. Adapun strategi dalam penelitian ini meliputi dua tahap, yaitu}

\section{Tahap Pengumpulan data:}

1. Studi kepustakaan dengan mengumpulkan data atau informasi dari buku-buku, literatur-literatur ataupun sumber pustaka lainnya, baik yang berkaitan dengan objek penelitian, teori maupun metode yang digunakan.

2. Observasi lapangan yaitu dengan melakukan pengamatan langsung pada objek kajian yang berada di lokasi penelitian yang terdiri atas objek tradisi megalitik di wilayah Kokas, Distrik Aifat Barat, dan wilayah Kampung Kombif dan SunWaban, Distrik Mare, Kabupaten Maybrat, dan lingkungan alam sekitarnya, serta lingkungan budaya masyarakat setempat.

3. Wawancara dilakukan dengan beberapa tokoh masyarakat yang dianggap tahu dan memahami dengan benar tentang kebudayaannya dan objek yang kaji oleh peneliti.

Tahap pengolahan data:

Seluruh data dan informasi yang berhasil dihimpun dalam penelitian ini selanjutnya dianalisis dan dibahas. Tahap analisis diawali dengan pengidentifikasian data, kemudian melakukan pendeskripsian semua bentuk data arkeologi yang ada dan diklasifikasikan berdasarkan jenis kemudian untuk bangunan megalitik akan dikaji dengan analisis morfologi dan pola tata letak. Selain itu, juga akan dilakukan penggambaran posisi lokasi situs terhadap pemukiman masyarakat dan sumberdaya alam lainnya.

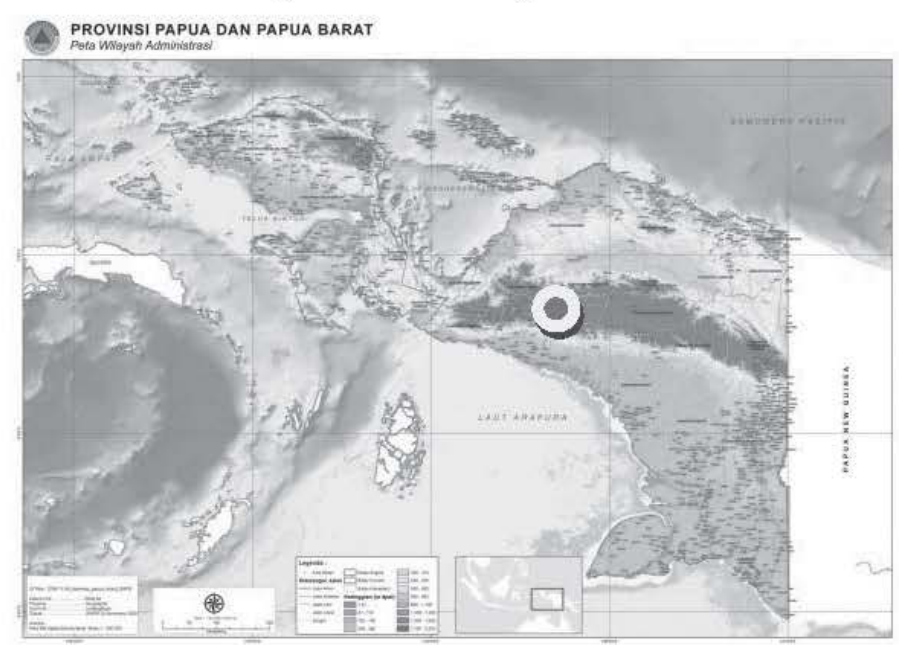

Gambar 1. Letak Kabupaten Maybrat Provinsi Papua Barat (Sumber: google map)

\section{TinggalanMegalitik Situs Kocuata}

Kocuata adalah penggabungan nama klan dan sebuah nama tempat, yaitu nama klan "kocu" dan nama tempat "ata". Jadi kocuata merupakan perkampungan lama/tua milik klan Kocu. Di situs Kocuata ditemukan temuan peninggalan bangunan tradisi megalitik. Tinggalan bangunan tradisi megalitik di Situs Kocuata berupa susunan atau struktur batu-batu kecil berbentuk persegi panjang,dan menunjukkan adanya pembagian ruang. Struktur megalitik ini memiliki panjang 7,43 meter dan lebar 3,30 
meter dengan orientasi barat lauttenggara dan barat daya-timur laut.

Disebelah timurlautterdapatpohon cemara yang bagi masyarakat dikaitkan sebagai totor atau tempat beristirahat arwah orang mati. Sedangkan bahan batuan yang digunakan adalah jenis

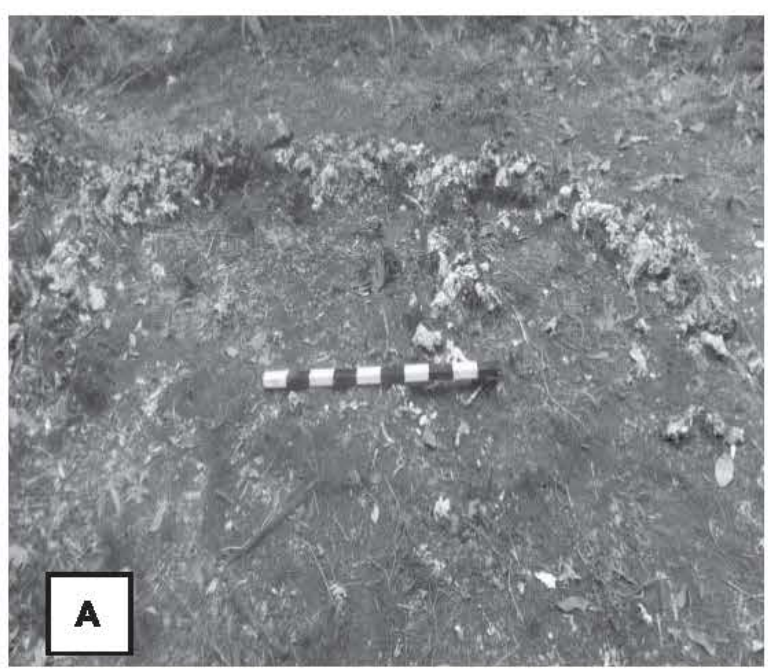

batu gamping koral. Etnohistori setempat menyatakan bahwa Situs Kocuata merupakan tempat bertemu untuk kegiatan adat yaitu pembayaran mas kawin, pengumpulan kain timur dan pembayaran hutang dari pihak satu ke pihak lain.

Gambar 2. BentukTinggalanMegalitik (A) dan gambar struktur megalitik (B) di Situs Kocuata (dokumentasi Balai Arkeologi Jayapura)

Peninggalan tradisi megalitik di Situs Kocuata tidak hanya berfungsi untuk kebutuhan-kebutuhan yang bersifat sakral, tetapi mencakup kebutuhan sehari-hari seperti pertemuan dan penyelesaian masalah sosial lainnya, sehingga tinggalan ini dapat dikelompokkan pada jenis tinggalan megalitik areosali yaitu suatu teras yang digunakan untuk menyelesaikan suatu masalah.

$\begin{array}{llr}\begin{array}{c}\text { Pembagian } \\ \text { bangunan }\end{array} & \begin{array}{c}\text { ruangan } \\ \text { megalitik }\end{array} & \text { pada } \\ \text { memungkinkan } & \text { adanya stratifikasi }\end{array}$
sosial. Dalam setiap masyarakat selalu mempunyai sesuatu yang dihargai. Sesuatu itu adalah dapat berupa kekayaan, ilmu pengetahuan, status kebangsawan, kekuasaan, atau hal-hal yang bersifat ekonomis. Berdasakan pandangan ini, maka diceritakan bahwa dengan meniup alat musik triton, tentang Kosata (moyang dari marga Kocu) mampu mengumpulkan kain timur dari berbagai tempat. Bahkan, di situs ini juga ada penyelesaian hutang piutang dari Ahah kepada Kosata. Cerita rakyat tersebut digambarkan melalui fitur struktur batu dengan pembagian ruang di dalamnya.
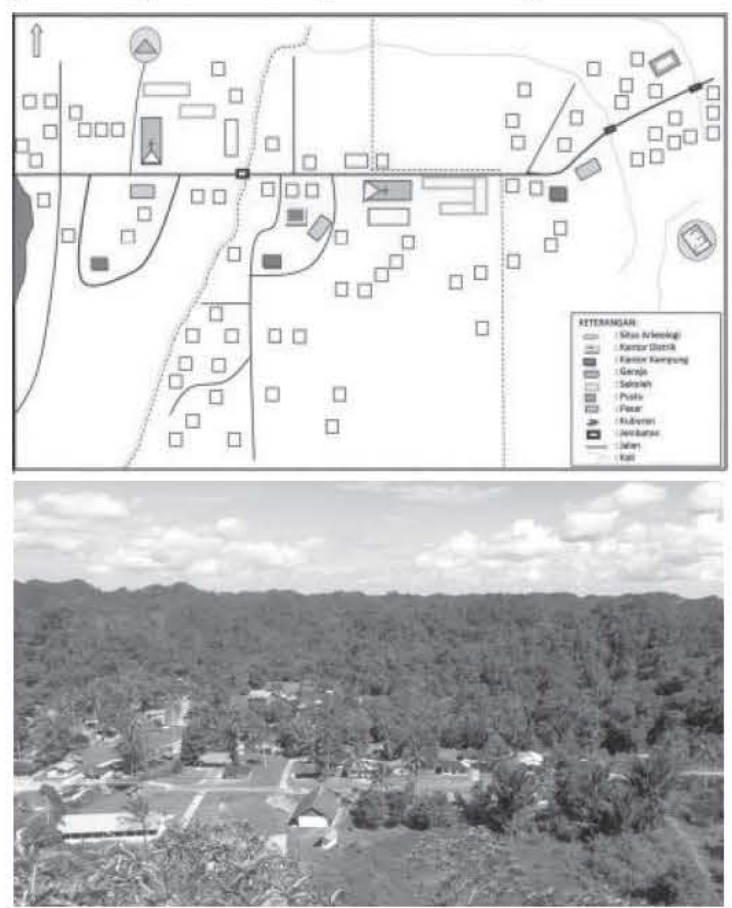

Gambar 3. Lokasi Situs dan Lingkungan Wilayah Kokas (dokumentasi Balai Arkeologi Jayapura) 


\section{Tempat Keramat (totor)}

Selain tinggalan tradisi megalitik di Kokas, ditemukan juga tradisi megalitik lainnya di wilayah Distrik Mare, yaitu Kampung Lama Kombif dan Kampung Sub-Waban. Bangunan tradisi megalitik yang ditemukan adalah berupa tempat keramat atau masyarakat setempat menyebutnya dengan istilah totor (tempat menghias/dekorasi arwah orang mati). Di Kampung Lama Kombif ditemukan dua lokasi totor. Totor pertama milik keret Bamero dan Baru. Keletakan astronomis lokasi totor berada pada koordinat tersebut diantara $00^{\circ} 56^{\prime} 31.8$ " Lintang Selatan dan $132^{\circ} 18^{\prime} 32.3^{\prime \prime}$ Bujur Timur. Pada areal totor ini terdapat pohon damar yang di sekitarnya digantungkan benda-benda berupa pakaian, termos, radio tape, dan bangku bekas,dan potongan kain berwarna merah yang diikatkan pada beberapa ranting pohon tersebut. Semua bendatersebut milik simati pada masa hidupnya. Di areal ini juga ditemukan sebongkah batu gamping dan tiga bongkah batu andesit yang didirikan secara sejajar.

Totor kedua adalah milik marga Nauw. Susunan sepuluh batu gamping dengan jumlah 10 buah dengan yang bentuk membujur timur-barat didirikan pada totor marga Nauw. Adapun luas susunan batu ini adalah panjang $160 \mathrm{~cm}$ dan lebar $110 \mathrm{~cm}$. Selain itu, di sisi timur dari susunan batu ini dibentangkan kain berwarna merah. Setiap pohon yang mengelilingi susunan batu tersebut salaing diikat dengan dan pepohononan sekitarnya diikatkan kain yang menyerupai pita berwarna merah.
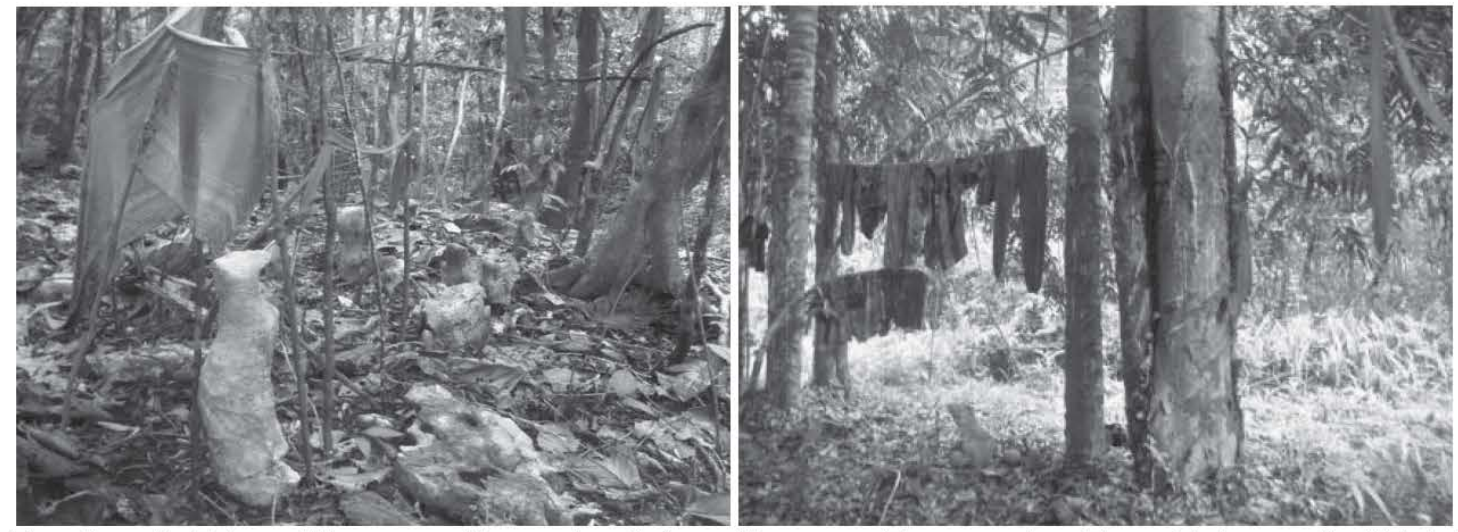

Gambar 4. Totor milik marga Nauw dan totor milk marga Bamero dan Baru (dokumentasi Balai Arkeologi Jayapura)

Lokasi totor lainnya adalah di Kampung Sun-Wabantotor ini adalah milik marga Yewen. Lokasi totor Reba berada dekat dengan jalan raya menuju Kampung Seya atau berada pada sebelah kiri, sedangkan Atafuk berada di kanan jalan raya. Kedua lokasi totor disebut reba dan atafuk. Keletakan astronomis situs reba tersebut di antara $00^{\circ}$ 57' 55.6" Lintang Selatan dan $132^{\circ}$ 19'17.4" Bujur Timur. Di Situs Reba ditemukan satu tengkorak kepala manusia, yang diletakkan di atas dahan pohon merbau. Menurut informan Bapak Leonardus Baru, bahwa tengkorak tersebut adalah tengkorak kepala dari Bapak Utihaen Yewen (tokoh masyarakat) yang meninggal sekitar tahun 1972.

Keletakan astronomis situs atafuk di antara $00^{\circ}$ 59'11.3" Lintang Selatan dan $132^{\circ} 20^{\prime}$ 58.8" Bujur Timur. Di sekitar lokasi Situs Atafuk terdapat peralatan dari simati berupa pakaian, termos, radio, microphone. Di lingkungan situs juga terdapat hiasan potongan kain merah yang diikatkan 
pada dahan-dahan pohon dan pakaian yang digantung pada tali dan dilkatkan diantara dahan pepohonan.

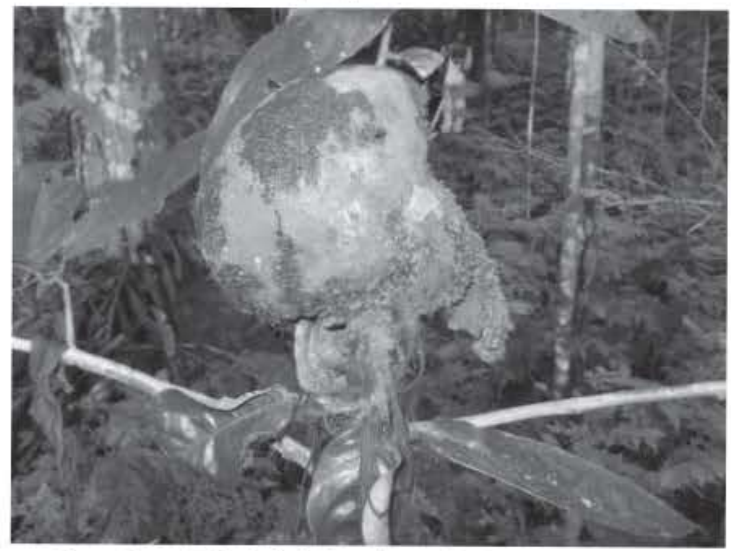

Gambar 5. Foto Tengkorak kepala Bapak Utihaen Yewendi Situs Reba (dokumentasi Balai Arkeologi Jayapura)

Berdasarkan data artefak, tempat keramat atau totor yang ditemukan di Kampung Lama Kombif dan Kampung Sun-Waban,yang ditemukan maka situs tersebut difungsikan sebagai tempat menghias/ dekorasi arwah orang mati. Kedua situs tersebut diindikasikan sebagai tempat bersemayamnya arwah keluarga yang sudah meninggal dan mereka menganggap bahwa arwah tersebut masih ada dan mampu memberikan perlindungan kepada keluarga yang ditinggalkan. Pemanfaatan totor dihiasi dengan adanya benda-benda berupa potongan-potongan kain merah yang dilikatkan pada tiang-tiang kayu yangmengelilingi lokasi totor. Penggunaan kain warna merah dapat melambangkan suatu keadaan darurat, bahaya, keberanian, kepahlawanan dan kepemimpinan.

Selain itu, terdapat pula bendabenda dari simati yang dianggap kesayangan atau benda yang sering digunakan semasa hidupnya, seperti pakaian, termos, bangku duduk, radio tape, dan piring makan. Di lain pihak, keberadaan batu andesit yang ditegakkan di lokasi totor (milik keret Bameru, Baru dan Nauw di Kampung
Lama Kombif) dapat diperkirakan bahwa keberadaan batu tersebut merupakan tanda batas wilayah totor (sesuai pembagian wilayah tanah adat).

\section{Peran Tinggalan Tradisi Megalitik}

Tinggalan struktur bangunan batu Situs Kocuata dan temuan totor di Kampung Lama Kombif dan kampung Sun-Wabanmerupakan bentuk tinggalan tradisi megalitik berlanjut (iving megalitik tradition). Struktur bangunan batu Situs Kocuata berfungsi sebagai tempat pembayaran atau tempat menyelesaikan masalah hutang piutang, tinggalan ini dapat dikelompokkan pada jenis tinggalan megalitik areosali, yaitu suatu teras yang digunakan untuk menyelesaikan suatu masalah (Sukendar, 1988:3).

Keberadaan Situs Kocuata dapat dikatakan sebagai tempatupacarayang berhubungan dengan pembayaran dan pelunasan hutang piutang. Tradisi megalitik ini masih tampak dalam budaya orang Maybrat seperti pembayaran maskawin, pembayaran denda, dan pelunasan hutang piutang. Tradisi ini menggambarkan stratifikasi sosial dalam pembagian harta, misalnya keturunan raja ataupun status pendidikan tinggi. Dengan demikian, pembagian harta kepada pemegang kedua status sosial tersebut lebih tinggi. Harta yang dimaksud dalam konteks ini adalah kain timur; berdasarkan kain timur juga dilihat dari bentuk dan bahannya, jika semakin lama (tua), kain timur tersebut maka semakin tinggi nilainya.

Dalam perkembangan sekarang, selain kain timur, pembayaran adat dilakukan dengan uang. Situs Kocuata dan cerita rakyat yang melatarbelakanginya juga turut berperan dalam aktivitas budaya masyarakat Kokas. Kosata 
sebagai moyang dari keret Kocu tampak diwariskan dalam sistem kepemimpinan kepala kampung yang selalu diwariskan kepada keret Kocu.

Totor di Kampung Kombif dan Sun-Waban, Distrik Mare merupakan tempat bersemayamnya arwah keluarga orang yang sudah meninggal dan arwah tersebut dianggap mampu memberikan perlindungan kepada keluarga yang ditinggalkan. Lokasi totor dihiasi dengan benda-benda berupa potongan kain merah, diikatkan pada tiang-tiang kayu dan mengelilingi lokasi totor, juga benda-benda kesayangan yang digunakan oleh simati semasa hidupnya (Fairyo, et.al, 2014).

Totor merupakan bentuk tinggalan tradisi megalitik. Esensi tradisi totor adalah percaya bahwa arwah nenek-moyang yang telah meninggal, masih hidup terus didunia arwah. Masyarakat Kampung Kombif dan Sun-Waban percaya bahwa kehidupan mereka sangat dipengaruhi oleh roh nenek-moyang. Keamanan,

\section{PENUTUP}

Diperkirakan bahwa kehadiran tradisi megalitik di wilayah Maybrat berasal dari pengaruh pertama yang melalui Indonesia sebelah selatan lewat kepulauan Maluku menuju bagian barat Papua. Bentuk tinggalan tradisi megalitik di Kampung Kokas adalah berupa struktur bangunan dari batu kecil berbentuk persegi panjang dan terdapat pembagian ruang. Bahan batuan yang digunakan adalah jenis batu gamping koral. Situs Kocuata menurut cerita lisan yang berkembang merupakan tempat pertemuan dari moyang Kosata ketika melakukan pembayaran dan pelunasan hutang piutang kain timur juga pembagian daging babi. Tinggalan ini dapat dikelompokkan pada jenis tinggalan kesehatan, kesuburan dan lain-lain sangat ditentukan oleh bagaimana perlakuan mereka terhadap arwah nenek-moyang mereka.yang telah meninggal. Dengan perlakuan yang baik masyarakat Kampung Kombif dan Sun-Waban mengharapkan perlindungan agarselalu terhindar dari ancaman bahaya (Sukendar, 1998:1).

Masyarakat Maybrat, khususnya di Kampung Kombif dan Sun-Waban, mempertahankan tradisi totor. Hal ini tampak dalam adat istiadat mereka, meskipun mereka merantau keluar kampung asalnya, karena pendidikan ataupun pekerjaan, kemudian mendengarberita adaanggotakeluarga yang meninggal dan tidak sempat menghadiri ibadah pemakaman maka suatu ketika jika mereka pulang ke kampungnya asalnya maka mereka dapat melakukan tradisi totor tersebut, hal ini dilakukan sebagai tanda kasih sayang, penyesalan tapi juga penghormatan bagi saudara mereka yang telah meninggal.

megalitik areosali.

Sedangkan tinggalan megalitik lainnya adalah tradisi totor, ditemukan di Kampung KombifdanSun-Waban. Totor merupakan tempat bersemayamnya arwah orang sudah meninggal dan arwah tersebut dianggap mampu memberikan perlindungan kepada keluarga yang ditinggalkan. Terkait tinggalan arkeologi yang ditemukan, maka dapat diasumsikan bahwa peran tradisi megalitik bagi masyarakat di wilayah ini masih mempengaruhi alam pikir mereka. Sebagai bukti cerita tentang penemuan kain timur di Situs Syaut maupun Situs Kocuata terus terpatri dalam pikiran masyarakat Kokas khususnya keret Kocu, juga tradisi totor masih dipertahankan oleh 
masyarakat setempat sebagai tanda penyesalan atas kepergian anggota keluarga, tapi juga tanda penghormatan dan kasih sayang. Tradisi megalitik di Situs Kocuata perlu dilestarikan bagi generasi muda sekarang, terutama nilai-nilai yang terkandung di dalamnya, sebagai bagian dari identitas masyarakat setempat. 


\section{DAFTAR PUSTAKA}

Djami, Erlin Novita Idje. 2009. "Pengelolaan Situs Megalitik Tutari: Studi Pengembangan". Jurnal Arkeologi Papua Vol. 1 No.1 Juni 2009. Balai Arkeologi Jayapura.

Fairyo Klementin, Zubair Mas'ud, Sri Chirullia Sukandar. 2014. Laporan Eksplorasi PeninggalanArkeologidan EtnoarkeologidiDistrikMare, KabupatenMaybrat, Provinsi Papua Barat. Balai Arkeologi Jayapura.

Fairyo Klementin, Erlin N. I. Djami, Amurwani Putri. 2015. Laporan Penelitian Tinggalan Tradisi Megalitik di Distrik Aifat Barat, Kabupaten Maybrat, Provinsi Papua Barat. Balai Arkeologi Papua.

Kawer Sonya, Erlin N. I Djami, Amurwani Putri. 2014. Laporan Penelitian Eksplorasi Arkeologi di Distrik Bomakia, Kabupaten Bovendigul. Balai Arkeologi Papua.

Mene, Bau, Djami Erlin, 2014. Laporan Penelitian Eksplorasi Arkeologi di Situs Gunung Srobu, Desa Abepantai, Kota Jayapura. Balai Arkeologi Papua.

Mene, Bau. 2013. Laporan Penelitian Arkeologi di Distrik Yokari dan Distrik Depapre Kabupaten Jayapura. Balai Arkeologi Jayapura.

Prasetyo, Bagyo. 2004. Religipada MasyarakatPrasejarahdilndonesia. Kementerian Kebudayaan dan Pariwisata, Proyek Penelitian dan Pengembangan Arkeologi.

Suroto, Hari, Rini Maryone dan Zubair Mas'ud. 2009. Laporan Penelitian Arkeologi di Kampung Arefi, Distrik Selat Sagawin, Kabupaten Raja Ampat. Balai Arkeologi Jayapura.

Suroto, Hari. 2014. Laporan Penelitian Eksplorasi Peninggalan Arkeologi dan Etnoarkeologi di Kabupaten Mamberamo Tengah. Balai Arkeologi Jayapura.

Soejono, R. P. 1994. "Prasejarah Irian Jaya" dalam Koentjaraningrat (ed). Irian Jaya Membangun Masyarakat Majemuk. Jakarta: Djambatan.

Sukendar, Haris. 1998. Album Tradisi Megalitik di Indonesia. Departemen Pendidikan dan Kebudayaan.

Tim peneliti. 2010. Laporan Penelitian Arkeologi Prasejarah di Pulau Misool, Kabupaten Raja Ampat. Balai Arkeologi Jayapura. 